\title{
Development and Psychometric Investigation of Career Problems Inventory for Bipolar Disorder Patients
}

\section{Zeinab Rostami}

University of Isfahan

Mohammad Reza Abedi ( $\nabla$ m.r.abedi@edu.ui.ac.ir)

University of Isfahan Faculty of Educational Sciences and Psychology

Parisa Nilforooshan

University of Isfahan

Keywords:

Posted Date: September 23rd, 2020

DOI: https://doi.org/10.21203/rs.3.rs-74206/v1

License: (c) (i) This work is licensed under a Creative Commons Attribution 4.0 International License.

Read Full License 


\section{Abstract}

The authors have requested that this preprint be removed from Research Square. 